Article

\title{
Legislation, Regulations, and Reflections on Environmental Accounting as a Reflection of the Incorporation of Social Responsibility in Companies
}

\author{
Maripaz Muñoz Prieto
}

CEU International Doctoral School, CEU San Pablo University, 28003 Madrid, Spain; mar.munoz@ceindo.ceu.es

Received: 14 April 2020; Accepted: 2 June 2020; Published: 5 June 2020

\begin{abstract}
The purpose of this article is to analyze how accounting legislation has contributed to the improvement of public information on environmental aspects in the financial reports issued by companies. Also, the article aims to verify the relationship between this environmental accounting legislation and the processes of corporate social responsibility. These reports are used for decision making, so any improvement in the publication should mean a better business strategy. Companies should seek to improve their relationship with the environment, helping to minimize the environmental problems caused by their production systems. The methodology used in this study has been the deductive method, through the bibliographic review, and a descriptive research level was used. Among the main results of this work are a summary table with regulations related to environmental care, evidence of the lack of specific legislation, and the need for more demanding regulations with companies when providing environmental data.
\end{abstract}

Keywords: accounting legislation; environmental accounting; corporate social responsibility; sustainable development

\section{Introduction}

The environment constitutes the place in which society carries out its activities, so we can say that it is one of the aspects to be considered in any type of action due to the effects it causes, both positive and negative, in this environment. Our lifestyle and business models have multiplied our society's conflicts with Nature. Problems such as pollution, climate change, environmental accidents, deforestation, degradation of the ozone layer, or overpopulation have carved a niche in our society and are increasingly important in our lives. Over the last few years, environmental issues have ceased to be of interest to small groups of ecologists, to become a concern of the general population (Ariel et al. 2001) and of companies in particular. Corporate social responsibility is an initiative that includes the involvement of companies with major social and environmental issues. For this, it is very important that the company establishes a commitment to transparency with the information it publishes through any of its communication channels.

Dahlsrud (2008) defines corporate social responsibility as a set of policies that companies adopt voluntarily in order to contribute adequately to society, contribute to the conservation of the environment, and maintain beneficial relationships with certain interest groups.

In order to show their compliance with Corporate Social Responsibility (CSR) goals, companies report their "sustainable initiatives" in their CSR reports. However, from small companies to multinational, it is hard to recognize the real benefits of sustainable strategies' implementation, since there are actually no general patterns defined which can ensure high impacts on sustainability (Déroche and Penzenstadler 2018). 
Accounting should serve the public interest and respond to the demands of sustainability, extending concern for accountability and sustainability not only to internal interest groups but to broader sectors of society such as universities, public institutions, nongovernmental organizations, government, and fair-trade organizations (Calero and Martinez 2017).

Worldwide, governments are attempting a unique combination of hard and soft legislation aimed at getting business to share responsibility for providing and sustaining a welfare state. In 2013, India legislated that large-sized companies must spend two percent of their net profit on priority issues such as poverty alleviation, capacity building, and environmental sustainability (Mukherjee 2017).

Also, the European Union (EU) legislation on electric and electronic equipment (EEE) has increased the externality costs of the electric appliances industry. Some companies only meet the minimum requirements of the legislation, while others go beyond what is required and engage in corporate social responsibility (CSR). The findings suggest that governments need to adapt their CSR policies not only to general sector-specific features, but in addition to the potential for reducing negative externalities in different parts of the value chain in each sector (Laudal 2012).

Measuring a firm's CSR performance requires a translation of the normative concept of sustainable development to the corporate level, such as to ensure that current decisions and activities do not jeopardize future generations in satisfying their own needs and wants. However, this does not make obsolete regulation and legislation about social rights and environmental standards (Hediger 2018).

The main objective of the present article is firstly to know the response of the Spanish accounting legislation to the environmental and sustainability challenge, and secondly, to analyze the emitted legislation by international organizations, which aims to regulate the environmental information in companies. The purpose of this article is also to verify how environmental accounting legislation influences corporate social responsibility processes focused on environmental aspects. The last objective will be to establish, in view of the analyzed legislation, a list of aspects that companies are required to publish.

\section{Materials and Methods}

This was a qualitative approach study, with a documentary bibliographic research, and descriptive in nature, through an analysis and interpretation of the current situation in Spain regarding the implementation of environmental accounting legislation, as well as international regulations.

The methodology that has been followed has been the review of documentation such as previous theses, scientific articles, books, communications, and current legislation.

The criteria applied for the search for information and the description of the main contributions of researchers to the topic have been the selection of the following keywords: accounting legislation, environmental legislation, environmental management, environmental accounting, corporate social responsibility, environmental responsibility, and sustainable development.

Consulting the Dialnet, Google Scholar, Science Direct, Scientific Library online (SCIELO), Teseo and Web of Science (WOS) databases allowed us to retrieve the material and bibliographic references, as well as check the degree of impact of the articles used. To this end, documentary and content analysis will be used as a working tool, aimed at formulating, from certain data, valid proposals that can be applied in the current context.

\section{Literature Review}

Since Rachel Carson (Carson 1962) began a stage of environmental awareness in the United States through her book "Silent Spring" until the declaration of the Sustainable Development Goals (SDGs), different paradigms or conceptual schemes have been produced (Colby 1991), which have collected the different relationships between humans and nature (Blanco Richart 2006); of note, the Frontier Economy (Boulding 1966), where Nature is treated as an infinite supply of physical resources (raw materials, water, soil, energy, air) or as an infinite sink for by-products (pollution and ecological degradation); the administration of resources (Meadows et al. 1972) with the publication of "The limits of growth" or 
Meadows report, where he proposed the collapse of the system in the 21st century, advocating Zero Growth against a limited natural environment, promoting the principle of "the polluter pays."

Also, from the international organizations they have included the environment within their policies and strategic lines. The different summits and conferences worldwide are those that have set the agendas in the activity of companies in social and environmental aspects. Among the most important are the following:

1. Sustainable development (Brundtland 1988): In this report from the World Commission on Environment and Development, the concept of "Sustainable Development" is coined (it appears in 1980 in the report of the International Union for the Conservation of Nature and Natural Resources, entitled "World Conservation Strategy"), defining it as "one that meets the needs of the present generation without compromising the ability of future generations to meet their own needs."

2. III Earth Summit in Rio de Janeiro (United Nations Program 1992): At the United Nations Conference on Environment and Development (UNCED), for the first time, worldwide, Sustainable Development is taken as a guide for the formulation of rational and regional development policies, that is, the integration between development and the environment.

3. Rights market (Kyoto Conference 1997): the most important consequence of the approval and ratification of the Kyoto Protocol is the start of international trade in emission rights, although it is not mandatory for the different countries that have ratified the Protocol, but a voluntary mechanism. Companies must analyze the costs of the two possibilities that are presented to them: one possibility will be to reduce the volume of emissions by modifying their production processes or by using cleaner processes (innovation) and the other option will consist of acquiring emission rights from others companies that do not reach the set limits (Tarruella 2005).

4. World Summit on Sustainable Development (Johannesburg 2002/Rio +10): This Summit was convened by the United Nations to review the achievements made since the 1992 Rio Summit. The basic documents that were approved at the Johannesburg Summit were a Political Declaration (The Johannesburg Declaration on Sustainable Development) of 32 points and an Action Plan (WSSD Plan of Implementation) of 153 points and 10 chapters. On the social side, the most prominent commitment was to halve by 2015 the number of people without access to health services. In natural resources, the two main agreements were to restore the level of depleted fisheries by 2015, where possible, and to significantly reduce the extinction rates of animals and plants by 2010. In terms of production and consumption patterns, it was decided to increase the share of renewable energies without setting percentages and years (Provencio 2002).

5. United Nations Conference on Sustainable Development 2012 (Rio de Janeiro, Rio +20): The official talks focused on two main themes: how to build a green economy to achieve Sustainable Development and lift people out of poverty and how to improve international coordination for Sustainable Development. The green economy or ecological economy could be defined as "an economy that results in improving human well-being and social equity, significantly reducing environmental risks and ecological scarcity" (UN Environment Program-UNEP official website). The global dimension of the current crisis (economic-financial, energy, food, environmental ...) has reduced the capacity of all countries to apply policies aimed at achieving sustainable development. The final document approved at the summit, "The future we want" (United Nations 2012), recognizes the existence of different visions, approaches, models, and instruments to achieve the general objective of sustainable development (Soloeta 2012, p. 4).

6. United Nations Summit on Sustainable Development 2015 (New York): It approved an Agenda entitled "Transforming our world: the 2030 Agenda for Sustainable Development" and which entered into force on 1 January 2016. The Sustainable Development Goals (SDGs) are the result of a negotiation process that has involved 193 member states of the United Nations and civil society and other stakeholders. The Agenda consists of 17 objectives and 169 goals (United Nations 2015). 
7. Paris Agreement 2015-2016: 195 out of the 197 countries that were part of the United Nations Framework Convention on Climate Change joined the environmental treaty approved on 12 December 2015, in Paris. It sets the goal of keeping temperatures rising "well below" two degrees Celsius from the pre-industrial era. Greenhouse gases emitted by human activity must be matched with levels that trees, soil, and oceans can naturally absorb. This objective, according to the treaty, must be achieved somewhere between the years 2050 and 2100 (European Union 2016).

8. COP24 in Katowice 2018 (Poland) sealed some minimum agreements that allow the application of the Paris Agreement. The outcome of the meeting highlighted the urgency of putting in place "urgent and unprecedented" measures to limit the increase in the planet's temperature to 1.5 degrees (United Nations 2018).

9. COP25 in Madrid 2019: up to 177 companies have supported the reduction of $\mathrm{CO}_{2}$ emissions, helping to limit the planet's temperature by $1.5^{\circ} \mathrm{C}$ until the end of the century and reaching the goal of zero emissions by 2050. Regarding the energy sector, a set of ten countries in Latin America and the Caribbean signed an agreement to increase the participation of renewable energies by $70 \%$ until 2030. It was also the first summit in which the 51 finance ministers met and the first time that they will launch the Santiago Action Plan to introduce climate change in the economic and financial policies of the different countries (United Nations 2019).

\subsection{Accounting and the Environmental Challenge}

An increasingly demanding partnership with companies to carry out their activities with responsibility and commitment has forced the accounting discipline to investigate new measurement, assessment, and control instruments. This has led accounting professionals to acquire new knowledge in corporate social responsibility, although many of them doubt that there is a relationship between ecology and accounting. Only "accounting can measure economic and environmental facts; and inform society in a reliable, timely and objective way of how some organizations are giving inappropriate use of environmental and social resources" (Mejia and Vargas Marín 2012).

Gomes et al. (2020) concluded in their study that the explanatory notes to the financial statements show that entities still do not take advantage of accounting and environmental management as mechanisms to measure their influence on the environment, and therefore, on their social responsibility.

The functions of accounting related to environmental management have generally been limited to traditional ones, such as the preparation and control of environmental budgets and the treatment of costs, although their role should be greater in the presentation of environmental information (Cerna 2017).

Traditionally, accounting has been considered as a set of techniques for recording economic facts, useful and necessary, but secondary for the development of the business economy (Carrasco Fenech and Larrinaga Gonzalez 1996).

Currently, this concept has evolved and, according to Wirth (2001), accounting is a "social technology," that is, a discipline that is concerned with aspects of the economic-social reality of organizations, with pragmatic objectives of solving information problems. This social basis of accounting makes accounting information reflect various social aspects that business activity influences, such as issues related to employees, the community, the environment, or ethics (Ariel et al. 2001).

The general purpose of accounting, as we already know, is to provide information to the different agents to help them make decisions, but this information is generally only available in the annual accounts. Among these is the environmental accounting information that will appear along with other types of information, since it can be financial or nonfinancial, quantitative or qualitative, mandatory (application of accounting standards) or voluntary.

Some authors (Zabala Luna 2016) distinguish four periods in environmental accounting. A first period would be the decade of the 1970s, in which social and environmental accounting emerged with the first theoretical reflections; a second period in the 1980s, where the criterion of true profit is used mostly. In the 1990s, the third period was directed towards the elaboration of social and environmental 
public information, due to the awareness on the part of society, and the last period would include the focus on the usefulness of decision-making, giving importance to environmental accounting dedicated to the securities markets and investors.

Mejia and Vargas Marín (2012) define environmental accounting as an applied social science that studies the qualitative and quantitative assessment of the existence and circulation of environmental wealth controlled by organizations, using various methods that allow it to evaluate the multiple controls that the organization exercises over the mentioned wealth, in order to contribute to the accumulation, generation, distribution, and comprehensive sustainability of it. According to this author, the environmental issue and its relationship with accounting covers three dimensions: environmental economic accounting system (monetary), environmental management accounting system (monetary), environmental accounting system (physical).

According to de la Rosa Leal (2019), the purpose of environmental accounting is to record the effects of the operation of organizations on natural resources and occupational health, so the interest of this accounting is to demonstrate the cost-benefit of preventive and/or corrective actions that can minimize or control the environmental effect.

Several authors of the accounting literature also point out in their articles the relationship between accounting information and corporate social responsibility. Larrinaga et al. (2019) tell us that, in view of the expansion of interest groups, the Intergovernmental Group of Experts on International Accounting and Financial Reporting Standards (ISAR) distinguished in 1977 the information to be included in the accounting reports of general use between: financial information and nonfinancial information. This distinction comes to be a consequence of the implantation of social responsibility in companies "especially regarding the use of human and natural resources, as well as the consequences that their operations may have on the environment."

Although environmental accounting alone is not considered sufficient to exercise control over environmental responsibility, it can be a tool that records and reports through its financial statements with environmental data. These states will collect in monetary terms what the company has invested to be socially responsible, and this information allows them to have competitive advantages over other companies that do not have this information (Amay-Vicuña et al. 2020).

\subsection{Legal Obligation to Provide Environmental Information}

For the company, there will be mainly four motivations (Fundació Fòrum Ambiental 1999) to provide environmental accounting information:

1. Legal requirements: the employer complies, at first, with current legal regulations.

2. Economic reasons: the increasing regulations may force managers to control their environmental risks more accurately in the face of the threat of sanctions, fines, or the administrative-criminal process, but also to reduce production costs and possibilities of accessing certain markets.

3. Environmental or internal management reasons: the company itself chooses to implement environmental management and its periodic control and monitoring.

4. Stakeholder or social image demands: companies are increasingly under pressure from interest groups.

We are going to deal with the first of the reasons: the legal requirement that companies have. The first legislative approach to environmental accounting information was the American Comprehensive Environmental Response Compensation and Liability Act (CERCLA, better known as the Superfund) of 11 December 1980, which dealt with legislating the responsibility produced by contaminated soils in that country (Bearden 2012). The first environmental regulations emerged that affect the accounting of the organizations have been five, all of them of European origin, one of them extended to the USA and Canada. In 1995, in the European Community, accounting awareness and its ethical commitment to ecology was an already important topic, which emphasized the need for a conceptual and methodological change in accounting, the revision of paradigms, and the need for 
accounting research in environmental issues (Chein Schekaiban and de la Rosa Leal 2007). It is in this context that the UN Statistics Division (UNSTATS) established in 1993 a debate forum called the London Group on Environmental Accounting, where international best practices were defined and collaborated in the development of the System of Environmental Accounting and Integrated Economy (SCAEI) and, in addition, the Accounting Advisory Forum elaborated in 1995 a series of recommendations on the inclusion of environmental aspects in financial accounting (Rodriguez 2014). Subsequently, the European Commission included a large part of these recommendations in a Binding Interpretation of the Fourth and Seventh Directives. It should be noted that the two issues included in this Binding Interpretation were the approach strategy to the international accounting standards of the International Accounting Standard Board (IASB) and the environmental information itself (Abadía et al. 2002).

In relation to the environmental accounting regulations set forth in the previous paragraph, an analysis of these first regulations is presented below in Table 1:

Table 1. Analysis of the first environmental accounting regulations.

\begin{tabular}{|c|c|c|c|c|}
\hline Year & Normative & Country & $\begin{array}{c}\text { Responsible for } \\
\text { Issuance }\end{array}$ & Citation \\
\hline 1993 & $\begin{array}{l}\text { Proposal for environmental } \\
\text { accounting information } \rightarrow \\
\text { National Accounting Manual: } \\
\text { Integrated environmental and } \\
\text { economic accounting. }\end{array}$ & Europe & European Union/SEEA & $\begin{array}{l}\text { Available online: https: } \\
\text { //unstats.un.org/unsd/publication/ } \\
\text { SeriesF/SeriesF_61E.pdf }\end{array}$ \\
\hline 1996 & Statement of position $96-1$ & $\begin{array}{c}\text { USA } \\
\text { Canada }\end{array}$ & $\begin{array}{c}\text { USA } \rightarrow \text { AICPA } \\
\text { CICA }\end{array}$ & $\begin{array}{l}\text { Available online: https: } \\
\text { //unstats.un.org/unsd/publication/ } \\
\text { SeriesF/SeriesF_61E.pdf }\end{array}$ \\
\hline 1997 & $\begin{array}{l}\text { Environmental financial } \\
\text { accounting and reporting at } \\
\text { the corporate level }\end{array}$ & $\mathrm{UN}$ & $\mathrm{UN} \rightarrow \mathrm{ISAR}-\mathrm{UNCTAD}$ & $\begin{array}{l}\text { Available online: } \\
\text { https://unctad.org/en/Docs/ } \\
\text { c2isard2.en.pdf }\end{array}$ \\
\hline 1998 & FRS12 (management) & Britain & FRC/IASB & $\begin{array}{c}\text { Available online: } \\
\text { https: } \\
\text { //www.frc.org.uk/getattachment/ } \\
\text { 8852999f-c7d8-4f67-ab0b- } \\
\text { bf084b1647ff/FRS-12-Provisions, } \\
\text {-Contingent-Liabilities-and-Cont- } \\
\text { Sept-1998.pdf }\end{array}$ \\
\hline 1998 & IAS No 37 & International & IASC & $\begin{array}{c}\text { Available online: } \\
\text { http://www.icac.meh.es/ } \\
\text { Documentos/Contabilidad/2. } \\
\text { Internacional/020.NIIF-UE/020. } \\
\text { NIC\%20Vigente/370.NIC } \% 2037 \% \\
\text { 20Provisiones, \%20pasivos } \% \\
\text { 20contingentes } \% 20 y \% 20 \text { activos } \% \\
\text { 20contingentes.pdf }\end{array}$ \\
\hline 1998 & $\begin{array}{l}\text { International Auditing } \\
\text { Practice Statement } \\
\text { (IAPS)-1010: The } \\
\text { consideration of } \\
\text { environmental matters in the } \\
\text { audit of financial Statements }\end{array}$ & International & IFAC & $\begin{array}{c}\text { IFAC (1998). } \\
\text { 1010_Consideraciones sobre el } \\
\text { medio ambiente en la auditoría de } \\
\text { los estados financieros, en Normas } \\
\text { Internacionales de Auditoría, } \\
\text { IFAC_-IACJCE, Madrid }\end{array}$ \\
\hline 1998-2005 & $\begin{array}{l}\text { Study 6-Environmental } \\
\text { management in Organizations } \\
\text { (accounting management) }\end{array}$ & International & IFAC & $\begin{array}{c}\text { Available online: } \\
\text { https://www.ifac.org/system/files/ } \\
\text { publications/files/international- } \\
\text { guidance-docu-2.pdf }\end{array}$ \\
\hline 1998 & Sector adaptations & Spain & ICAC & $\begin{array}{c}\text { Available online: http: } \\
\text { //www.icac.meh.es/Normativa/ } \\
\text { DocumentosContabilidad.aspx }\end{array}$ \\
\hline
\end{tabular}


Table 1. Cont.

\begin{tabular}{|c|c|c|c|c|}
\hline Year & Normative & Country & $\begin{array}{l}\text { Responsible for } \\
\text { Issuance }\end{array}$ & Citation \\
\hline 2001 & $\begin{array}{l}\text { Recommendation 2001/453/EC } \\
\text { regarding the recognition, } \\
\text { measurement and disclosure } \\
\text { of environmental issues in the } \\
\text { annual accounts and annual } \\
\text { reports of companies of } 30 \\
\text { May 2001. C (2001) 1495 } \\
\text { (DOCE L 156, JUNE 13) }\end{array}$ & Europe & European Commission & $\begin{array}{l}\text { Available online: https:/op. } \\
\text { europa.eu/en/publication-detail/-/ } \\
\text { publication/1a83bbcd-33b0-4b27- } \\
\text { 8aaf-38d1225b02f7/language-en }\end{array}$ \\
\hline 2002 & $\begin{array}{c}\text { Corporate Social } \\
\text { Responsibility: A business } \\
\text { contribution to Sustainable } \\
\text { Development }\end{array}$ & Europe & European Commission & $\begin{array}{c}\text { Available online: } \\
\text { https://eur-lex.europa.eu/ } \\
\text { LexUriServ/LexUriServ.do?uri= } \\
\text { COM:2002:0347:FIN:EN:PDF }\end{array}$ \\
\hline
\end{tabular}

SEEA: System of Environmental-Economic Accounting; AICPA: American Institute of Certified Public Accountants; CICA: Canadian Institute of Chartered Accountants; ISAR: Intergovernmental Working Group of Experts on International Standards of Accounting and Reporting; UNCTAD: United Nations Conference on Trade and Development; FRC: Financial Reporting Council; IASC: International Accounting Standards Committee; IFAC: International Federation of Accountants; ICAC: Instituto de Contabilidad y Auditoría de Cuentas/Accounting and Auditing Institute; Source: (Chein Schekaiban and de la Rosa Leal 2007; Tua Pereda 2002) and own elaboration.

As you can observe, the treatment of environmental aspects is a global problem, which has been picked up by various countries over the years.

\subsection{Environmental Accounting Legislation in Spain}

Spain is one of the pioneering EU countries in accounting regulation of environmental matters (Criado Jiménez et al. 2005) with the approval in 1998 of Royal Decree 437/1998, of 20 March, regarding the adaptation of the General Accounting Plan (GAP) to companies in the electricity sector, which included the obligation for all Spanish companies to present environmental information in the annual accounts.

Subsequently, this obligation was specifically regulated through the adaptations of the General Accounting Plan to the concession companies of highways, tunnels, bridges, and other toll roads; to companies in the water supply and sanitation sector; to the companies of the wine sector and to the Sports Public Limited Companies. However, and despite being pioneers in the sectoral adaptation of the GAP, it remains unregulated for the rest of the sectors.

On the other hand, in 2001, the Recommendation (2001/453/EC) of 30 May, on the recognition, measurement, and publication of environmental issues in the annual accounts, was published. In addition to this, the recommendation of the EC (2001/453/EC) recommends publishing the following information in the report: for each environmental responsibility of a certain importance, a description of its nature and mention of the calendar and payment conditions. An explanation of the damage and the rules or regulations that require its repair and the restoration or prevention measures that are being adopted or have been proposed; if the current valuation method has been used and the discount effect is of some importance, the undiscounted amount of liability and the type of discount used must be specified; in the case of long-term costs of restoration, closure and dismantling of contaminated sites, the accounting policy; the amount of the environmental expense entered in the profit and loss account and on what basis it is used to calculate such amount; provided that the amount of environmental expense capitalized during the reporting period can be reliably calculated. It should also be indicated, where appropriate, what part of the amount in question refers to expenses destined to eliminate contaminants after its creation and what part represents the additional expense to adapt the installation or the production process with a view to generating less contamination (for example, which refers to technologies or practices aimed at preventing pollution); provided that they are significant, the costs related to fines and penalties for noncompliance with environmental regulations and compensation paid to third parties should be indicated separately, if they have not already been indicated as extraordinary items, as a result, for example, of losses or damages caused 
in the past by environmental pollution; tax incentives related to environmental protection received by the company or to which it is entitled; the conditions of each affected item or, if they are similar, a summary of the conditions. The accounting treatment adopted must also be specified.

This recommendation tells us that "environmental damages that may be related to the company or may have been caused by it, but in relation to which there is no legal, contractual or tacit obligation to repair them, do not meet the requirements to be recognized as environmental responsibility in the company's annual accounts ...". The foregoing shows the formal nature of the recognition, since it is subject to a fact of legal formalization or voluntary acceptance. Furthermore, the text of the Community Recommendation (2001) endorses the breakdown of environmental items and provides that member states may impose more detailed subdivisions of the items provided for in the profit and loss account balance models for this purpose (Llodrà et al. 2008).

Pursuant to this Recommendation (2001/453/EC), member states should take measures to encourage companies to implement these recommendations. The adaptation of this Recommendation to national legislation in each member state of the European Union has been carried out in a diverse way, having on the one hand countries such as Spain or France that have followed their own accounting tradition through the issuance of accounting standards much more restrictive nationals, or countries like Portugal that have generally adopted the International Financial Reporting Standards (IFRS) (Abadía et al. 2002).

Although this standard is not strictly enforced for states or community companies, it has become a powerful reason for the Accounting and Auditing Institute (ICAC) to address an environmental accounting standard that responds to this community recommendation and, in addition, developed some aspects already included in the adaptation of the General Accounting Plan to electricity companies (Royal Decree 437/1998). (Abadía et al. 2002, p. 32). Therefore, although the ICAC Resolution was published in 2002, there was already an obligation for these companies to publish environmental information in their annual accounts since 1998, and the accounts and information requested in this accounting adaptation served to prepare the resolution of the 2002 ICAC.

The ICAC Resolution of 25 March 2002, constitutes the first specific accounting standard on environmental financial accounting in Spain. This standard included the Guidelines present in the Commission Recommendation of 30 May 2001, as well as other International Accounting Standard Board (IASB) standards (Figure 1). The scope of application of the ICAC Resolution extends to all Spanish accounting subjects, affecting both the individual and consolidated annual accounts, as well as nonprofit organizations. In addition, environmental aspects will have to be considered both by small- and medium-sized companies and by large corporations. This supposes to correctly recognize that the size of the companies does not have to affect the ecological significance of said entity (Abadía et al. 2002).

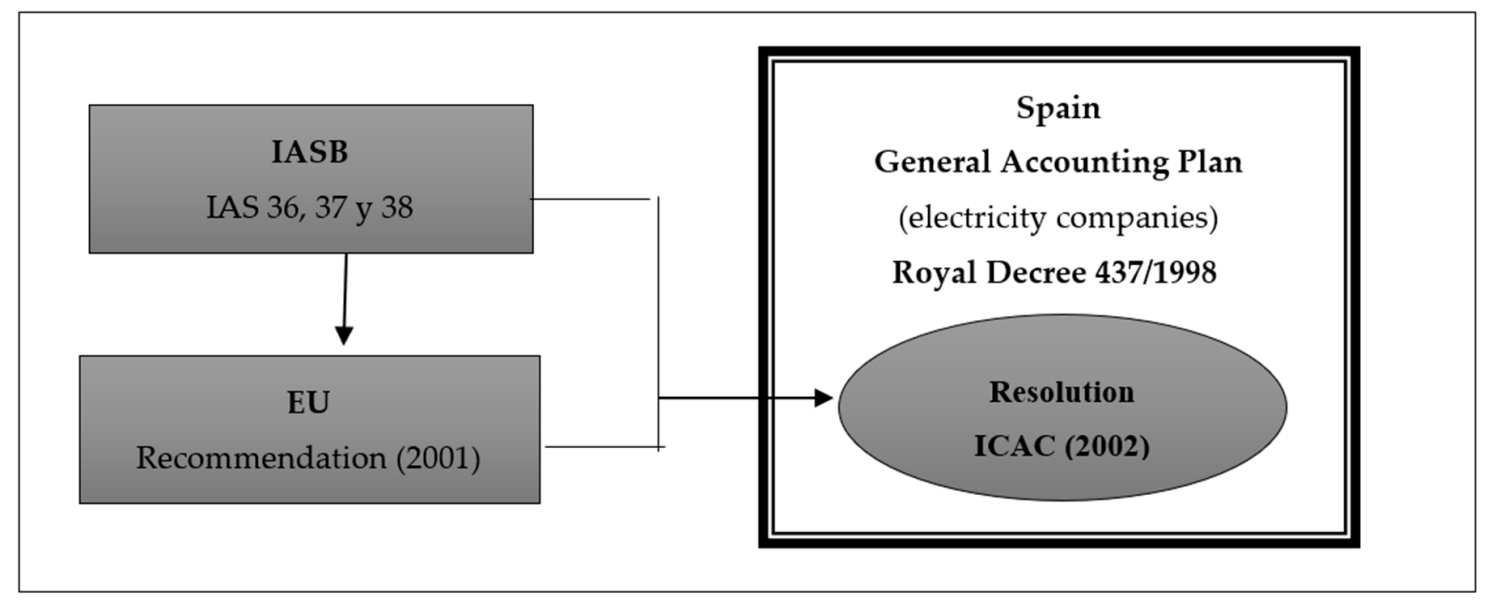

Figure 1. Background of the ICAC Resolution (2002); Source: Abadía et al. (2002, p. 950). 
The Resolution basically distinguishes two accounting responses to the ecological challenge, the first of which is the environmental financial accounting, based on the traditional accounting model, aimed at information on the financial aspects of companies' environmental actions, and the second is the environmental reporting or environmental information that would be nonfinancial information about the externalities produced by the business activity.

It can be verified that, in this first phase prior to the ICAC Resolution, the legislation only obliges companies in the electricity sector to provide environmental information on business actions with an impact on the environment and their assessment, provisions for environmental actions, repairs and conservation of the environment, equipment and facilities to minimize environmental effects, expenses for protection and improvement of the environment, and contingencies related to the environment. According to Deniz Mayor (2007), this standard focuses on purely financial aspects, as it does not require a description of the environmental impact or information on nonmonetary figures such as emissions. With the resolution of the ICAC, this obligation extends to the rest of the sectors that were not regulated through the sector plans and improves the accounting information because now the company must provide, in addition to the aforementioned, the accounting policies on decontamination and restoration, tax deductions for investments in measures to reduce impacts, full amounts of responsibilities and compensation to be received and subsidies received. Finally, it regulates three accounts to record environmental effects.

\subsection{Updating of Accounting Legislation from the ICAC 2002 Resolution}

In Spain, according to Royal Decree 1514/2007, of November 16, which approves the General Accounting Plan, the Report is the only annual statement or account in which the company can provide specific information on the environment and, more specifically, in its section 15 , information on the environment, although it may also be included in other sections such as, for example, within the valuation rules (point 4), or section 12; tax situation, which will include information on deductions for investment in measures to reduce environmental impact. In the general section on the environment, information will be provided on property, plant, and equipment aimed at protecting and improving the environment, on environmental expenses, risks and contingencies, as well as their estimation systems.

Traditionally, Financial Accounting incorporates environmental information in two different ways. On the one hand, the financial information will be present in the Balance Sheet, the Income Statement and partially in the Report, and on the other, if we talk about quantitative and qualitative information, it will be incorporated in the Report, the management report, and also in the auditors' report (Ariel et al. 2001).

In addition to the annual accounts, therefore, we will also have to take into account the information included in the Management Report. The Capital Companies Law regulates in Chapter III the content of the management report, which, although it is not an annual account, must be presented together with these. This Law does not explain the content of this report, but Directive 2014/95/EU of the European Parliament and of the Council does regulate the disclosure of nonfinancial information by certain large companies and certain groups, and also talks about environmental information. In section 7 of the introduction it states that "in the event that companies are required to prepare a non-financial statement, this statement must include, regarding environmental issues, detailed information on the current and foreseeable effects of the company's activities in the environment, and, where appropriate, health and safety, the use of renewable and/or non-renewable energy, greenhouse gas emissions, water consumption and atmospheric pollution."

The most current reference can be found in the last modification of the Spanish Commercial Code contained in Law 11/2018, of 28 December, where the obligations of companies are expanded (Small Medium Enterprise-SMEs have no obligation) regarding environmental information, as stated in the new section 6 of article 49, which tells us that the consolidated nonfinancial information statement will include significant information on the following issues: detailed information on the current and foreseeable effects of the company's activities on the environment; environmental assessment or 
certification procedures; resources dedicated to the prevention of environmental risks; the amount of provisions and guarantees for environmental risks; pollution (measures to prevent, reduce, or repair carbon emissions that seriously affect the environment; considering any form of atmospheric pollution specific to an activity, including noise and light pollution); circular economy and waste prevention and management (prevention, recycling, reuse, other forms of waste recovery and disposal; actions to combat food waste); sustainable use of resources (water consumption and water supply in accordance with local limitations; consumption of raw materials and the measures adopted to improve the efficiency of their use; consumption, direct and indirect, of energy, measures taken to improve energy efficiency and the use of renewable energy); climate change (the important elements of greenhouse gas emissions generated as a result of the company's activities, including the use of the goods and services it produces; the measures adopted to adapt to the consequences of climate change; the goals of voluntary reduction established in the medium and long term to reduce greenhouse gas emissions and the means implemented for this purpose); protection of biodiversity (measures taken to preserve or restore biodiversity; impacts caused by activities or operations in protected areas).

As a summary in Table 2, we can find the Spanish legislation dedicated to the regulation of environmental information in accounting, directly or indirectly.

Table 2. Spanish legislation on environmental information in accounting.

\begin{tabular}{|c|c|c|c|c|}
\hline Year & Normative & Country & $\begin{array}{l}\text { Responsible for } \\
\text { Issuance }\end{array}$ & Citation \\
\hline 1996-1999 & $\begin{array}{l}\text { Environmental Management } \\
\text { Accounting Regulations }\end{array}$ & Spain & AECA & $\begin{array}{l}\text { AECA (1996). Contabilidad de } \\
\text { Gestión Medioambiental. Doc. N. } \\
\text { 13. Serie Principios de } \\
\text { Contabilidad de Gestión. AECA. } \\
\text { Madrid. }\end{array}$ \\
\hline 2002 & $\begin{array}{c}\text { Resolution of } 25 \text { March 2002, of } \\
\text { the Institute of Accounting and } \\
\text { Auditing of Accounts, which } \\
\text { approves standards for the } \\
\text { recognition, valuation, and } \\
\text { information of environmental } \\
\text { aspects in the annual accounts. } \\
\text { (BOICAC n } n^{\circ} 49 / \text { March 2002-BOE } \\
\text { 04/04/2002) }\end{array}$ & Spain & ICAC & $\begin{array}{c}\text { Available online: } \\
\text { https://www.boe.es/buscar/doc. } \\
\text { php?id=BOE-A-2002-6389 }\end{array}$ \\
\hline 2007 & $\begin{array}{l}\text { The General Accounting Plan } \\
\text { (ROYAL DECREE 1514/2007, of } 16 \\
\text { November, BOE } \mathrm{n}^{\circ} 278 \text { ) }\end{array}$ & Spain & $\begin{array}{l}\text { Ministry of } \\
\text { Economy and } \\
\text { Finance }\end{array}$ & $\begin{array}{c}\text { Available online: } \\
\text { https://www.boe.es/buscar/doc. } \\
\text { php?id=BOE-A-2007-19884 }\end{array}$ \\
\hline 2007 & $\begin{array}{l}\text { LAW 26/2007, of } 23 \text { October, on } \\
\text { Environmental Responsibility } \\
\text { (BOE } 24 \text { October 2007). }\end{array}$ & Spain & Head of State & $\begin{array}{c}\text { Available online: } \\
\text { https://www.boe.es/buscar/act. } \\
\text { php?id=BOE-A-2007-18475 }\end{array}$ \\
\hline 2010 & $\begin{array}{c}\text { Royal Legislative Decree } 1 / 2010, \\
\text { of } 2 \text { July, which approves the } \\
\text { consolidated text of the Capital } \\
\text { Companies Law }\end{array}$ & Spain & $\begin{array}{l}\text { Ministry of the } \\
\text { Presidency }\end{array}$ & $\begin{array}{c}\text { Available online: } \\
\text { https://www.boe.es/buscar/act. } \\
\text { php?id=BOE-A-2010-10544 }\end{array}$ \\
\hline 2015 & $\begin{array}{l}\text { Law 22/2015, of } 20 \text { July, on } \\
\text { Accounts Auditing. }\end{array}$ & Spain & Head of State & $\begin{array}{c}\text { Available online: } \\
\text { https://www.boe.es/buscar/act. } \\
\text { php?id=BOE-A-2015-8147 }\end{array}$ \\
\hline 2018 & $\begin{array}{l}\text { Law } 11 / 2018 \text {, of } 28 \text { December, } \\
\text { amending the Commercial Code, } \\
\text { the consolidated text of the } \\
\text { Capital Companies Law approved } \\
\text { by Royal Legislative Decree } \\
\text { 1/2010, of } 2 \text { July, and Law } 22 / 2015, \\
\text { of } 20 \text { July, Audit of Accounts, in } \\
\text { matters of nonfinancial } \\
\text { information and diversity. }\end{array}$ & Spain & Head of State & $\begin{array}{c}\text { Available online: } \\
\text { https://www.boe.es/buscar/doc. } \\
\text { php?id=BOE-A-2018-17989 }\end{array}$ \\
\hline
\end{tabular}

AECA: Asociación Española de Contabilidad y Administración de Empresas/Spanish Business Administration and Accounting Association; Source: Own elaboration.

In summary, with respect to the legislation after the ICAC Recommendation, the improvements that this new legislation provides is an increase in the quantity and quality of environmental information, 
first through Directive 2014/95/EU that regulates information on current and foreseeable effects of the company's activities on the environment, the use of renewable and/or nonrenewable energy, greenhouse gas emissions, water consumption and air pollution, and subsequently with Law 11/2018, which adds to the foregoing the obligation to report, only in the consolidated reports, on environmental assessment or certification procedures, circular economy and waste prevention and management, sustainable use of resources, climate change and protection of biodiversity (Centeno 2017; Szadziewska et al. 2018). This Directive represents a substantial reinforcement of the content of the management report and an excellent opportunity to improve business transparency in the field of nonfinancial 'reporting' (Reverte Maya 2015). This legislation is completed by another that, although it does not regulate accounting aspects in themselves, it does provide information on definitions, responsibilities, obligations, and sanctions (Law 26/2007) that can be used in accounting.

\subsection{International Accounting Standards}

While the standardization of environmental information has been developed in the Spanish environment, an evolution in international standards has also been taking place. Notable forerunners are the U.S. standards issued by the Securities Exchange Commission (SEC) that introduced specific standards for the disclosure of environmental financial information in the annual accounts, and the Financial Accounting Standards Board (FASB) that has ruled on the recognition of various financial environmental aspects, which have been complemented by the Emerging Issues Task Force of the FASB (EITF) (Llodrà et al. 2008).

As it has been verified, the disclosure of accounting information related to the environment does not have technical support in a specific and unique standard. There are other types of international accounting or financial reporting standards, which are applicable to this type of item and include the treatment of environmental aspects in company reports. These standards are:

- The International Accounting Standards IAS-issued by the International Accounting Standard Board (IASB), first version 1998, last version 2012), especially: IAS 36 "Impairment of assets"; IAS 37 "Provisions, contingent assets and contingent liabilities": deals with environmental liabilities; IAS 38 "Intangible Assets": mainly refers to emission rights.

- International Financial Reporting Standards IFRS. (IASB-2009): IFRS 6: Exploration and evaluation of mineral resources, deals directly with extractive industries.

- IFRIC pronouncements: IFRIC 1: Changes in existing liabilities for decommissioning, restoration and the like (2004); IFRIC 5: Rights for Participation in Funds for Retirement from Service, Restoration and Environmental Rehabilitation (2004); IFRIC 6: Obligations arising from participation in Specific Markets—waste from electrical and electronic equipment (2005); IFRIC 20: Stripping costs in the production phase of an open-pit mine (2011).

The International Accounting and Financial Reporting Standards IAS/IFRS issued by the International Accounting Standards Board IASB is the model that is being widely implemented throughout the world. The issuance of environmental information, in many cases, is not enough to be able to affirm that there is an environmental commitment within the entity, because the information issued may not be adequate or pertinent, and therefore, the decisions made from such criteria will not be the most convenient for sustainability. Despite this importance, the IASB accounting model has not issued any IAS/IFRS that is directly related to environmental measurement, that is, "this accounting model does not allow the construction of a real representation of environmental resources. The regulation of the IAS/IFRS is a financial accounting model, in that sense it cannot be applied in a coherent way for environmental and social purposes," although it is true that it appears indirectly within some IAS/IFRS standards, which has allowed the development of some criteria for the recognition and valuation of environmental elements (Mejia Soto 2010).

According to Tua Pereda (2002), accounting standardization has had "a significant evolution, which shows the decided trend towards increasing consideration of the effect of environmental issues 
on financial reporting." This author includes a first stage in which there are "attempts to apply, in regulations not specifically dedicated to the environment, general concepts-the concept of provision, for example - to the effect of the company's environmental policy on its assets and results, as does, for example, the IASC in its IAS number 37." It also highlights a second stage, in which "specific pronouncements dedicated to the environment have been issued."

In Table 3 we can consult the European regulations that are related to the provision of information on environmental aspects in companies.

Table 3. European regulations on environmental information in accounting.

\begin{tabular}{|c|c|c|c|}
\hline Year & Normative & Responsible for Issuance & Citation \\
\hline 1996 & $\begin{array}{l}\text { SEC 95. Council Regulation (EC) No. } \\
2223 / 96 \text { of } 25 \text { June 1996, on the } \\
\text { European system of national and } \\
\text { regional accounts in the Community }\end{array}$ & European Council & $\begin{array}{c}\text { Available online: https: } \\
\text { //eur-lex.europa.eu/legal-content/EN/ } \\
\text { TXT/PDF/?uri=CELEX:52007PC0776\& } \\
\text { qid=1590490288150\&from=EN }\end{array}$ \\
\hline 1996 & $\begin{array}{l}\text { Council Regulation (EC, Euratom) No. } \\
58 / 97 \text { of } 20 \text { December 1996, on structural } \\
\text { business statistics }\end{array}$ & European Council & $\begin{array}{c}\text { Available online: https: } \\
\text { //eur-lex.europa.eu/legal-content/EN/ } \\
\text { TXT/PDF/?uri=CELEX:31997R0058\& } \\
\text { qid=1590490445635\&from=EN }\end{array}$ \\
\hline 1998-2012 & $\begin{array}{l}\text { The International Accounting Standards } \\
\text { (IAS) }\end{array}$ & $\begin{array}{c}\text { International Accounting } \\
\text { Standard Board } \\
\text { (IASB) }\end{array}$ & $\begin{array}{l}\text { Available online: https: } \\
\text { //www.iasplus.com/en/standards/ias }\end{array}$ \\
\hline 2001 & $\begin{array}{l}\text { Recommendation 2001/453/EC of the } \\
\text { European Commission regarding the } \\
\text { recognition, measurement, and } \\
\text { disclosure of environmental issues in } \\
\text { the annual accounts and annual reports } \\
\text { of companies, of } 30 \text { May 2001. C ( } 2001 \text { ) } \\
1495 \text { (DOCE L 156, JUNE 13) }\end{array}$ & European Commission & $\begin{array}{c}\text { Available online: } \\
\text { https://op.europa.eu/en/publication- } \\
\text { detail/-/publication/1a83bbcd-33b0- } \\
\text { 4b27-8aaf-38d1225b02f7/language-en }\end{array}$ \\
\hline 2004-2017 & IFRIC interpretations & IFRIC & $\begin{array}{c}\text { Available online: } \\
\text { https://www.ifrs.org/issued-standards/ } \\
\text { list-of-interpretations/ }\end{array}$ \\
\hline 2009 & $\begin{array}{l}\text { International Financial Reporting } \\
\text { Standards IFRS }\end{array}$ & IASB & $\begin{array}{l}\text { Available online: https://www.ifrs.org/ } \\
\text { issued-standards/list-of-standards/ }\end{array}$ \\
\hline 2010 & $\begin{array}{l}\text { Conceptual Framework for the } \\
\text { Preparation and Presentation of } \\
\text { Financial Statements published in } 1989 \\
\text { by the IASB, later revised and published } \\
\text { in September } 2010 \text { as the Conceptual } \\
\text { Framework for Financial information }\end{array}$ & IASB & $\begin{array}{l}\text { Available online: https://www.ifrs.org/-/ } \\
\text { media/project/conceptual-framework/ } \\
\text { fact-sheet-project-summary-and- } \\
\text { feedback-statement/conceptual- } \\
\text { framework-project-summary.pdf }\end{array}$ \\
\hline
\end{tabular}

Source: Own elaboration.

\subsection{Other Environmental Accounting Legislation in the International Arena}

In addition to the legislation and regulations that have been previously exposed, there are other important international accounting documents related to the collection of environmental aspects. Below are some of these documents:

- $\quad$ EUROPEAN UNION (2001). Regulation (EC) 761/2001, which allows organizations to voluntarily adhere to a community environmental management and audit system (EMAS). TWELVE 24.4.2001

- Global Reporting Initiative (GRI 2002) or the Commission of Responsibility Social Corporate AECA (RSC 1, 2004)

- In the United States, Statement of Position (SOP) 96-1: Environmental Remediation Liabilities, in 1996, issued by the American Institute of Certified Public Accountants (AICPA)

- In Canada, the Canadian Institute of Chartered Accountants (CICA) published in 1996 "Handbook: International Accounting Standards Section 1501". 
- Works issued by the International Federation of Accountants (IFAC), Auditing Standard No. 1010 "Environmental considerations in the audit of financial statements" and Study 6-Environmental management in organizations

- The United Nations Intergovernmental Working Group of Experts on International Standards of Accounting and Reporting (ISAR) published the report "Accounting and Financial Reporting for Environmental Costs and Liabilities" in 1998.

- Law 8/1994 of 24 June on Environmental Impact Assessment

- In the European Union, the issuance of the interpretation of the 4th and 7th directives in 1998 Accounts Directive of the European Union (EU, 1998)

- The White Paper on Environmental Responsibility (European Commission 2000)

- Green Paper: Fostering a European framework for corporate social responsibility (European Commission 2001)

- $\quad$ Triple bottom line: Does it all Add UP (2004)

- Global Compact on Social Responsibility (2000) UN

- OECD Guidelines for Multinational Enterprises (2000)

- ILO Tripartite Declaration on International Business and Social Policy (1977-2000)

- $\quad$ normaAA-1000- November 1999, Institute of Social Ethical Accountability

- SA-8000: Council on Economic Priorities Accreditation Agency (CEPAA)

- System of Environmental-Economic Accounting 2012: Experimental Ecosystem Accounting-final, official publication (2014)

- System of Environmental-Economic Accounting 2012: Applications and Extensions-white cover publication (2014)

- System of Environmental-Economic Accounting 2012: Central Framework-final, official publication (2014)

- System of Environmental-Economic Accounting 2012: Experimental Ecosystem Accounting-white cover publication (2013)

- System of Environmental-Economic Accounting 2012: Central Framework-white cover publication (2012)

- Monitoring Framework for Water: Briefing Note on The System of Environmental-Economic Accounts for Water (SEEA-Water) and the International Recommendations for Water Statistics (IRWS) (2011)

- International Recommendations for Water Statistics (IRWS) (2010)

- $\quad$ System of Environmental-Economic Accounting for Water (SEEA-Water) (2007)

- Handbook of National Accounting: Integrated Environmental and Economic Accounting for Fisheries (SEEA-F) (2004)

- Handbook of National Accounting: Integrated Environmental and Economic Accounting 2003 (SEEA 2003)

- Handbook of National Accounting: Integrated Environmental and Economic Accounting-An Operational Manual (2000)

- Handbook of National Accounting: Integrated Environment and Economic Accounting 1993 (SEEA 1993)

\section{Results and Discussion}

According to a study by González (2008), the publication of environmental accounting information in Spanish companies was almost nonexistent until the end of the 20th century, and at the moment, most companies did not present environmental information in their annual accounts, or they only included little relevant environmental information, generally responding to the intention of presenting a friendly corporate image in the presence of significant environmental impacts. 
There is an improvement in the implementation of environmental accounting due to the implementation of the different laws approved. In a first phase, we have considered the previous legislation of the ICAC 2002 Recommendation, where progress is small, but helps to establish the basis for the following legal measures, and a phase after said Resolution where the improvements made in the provision of information, both quantitative and qualitative, have been found to be considerable.

The approach adopted by the Spanish accounting regulation is limited to an answer in monetary terms, without including data on environmental and environmental variables in physical terms, so that the hypothetical improvements produced will remain outside the knowledge of the interest groups, because the degree of effectiveness and efficiency of the actions taken cannot be measured. Perhaps some rule on incentive disclosure could be introduced, as is the case in the United States, so that companies that recognize the possible occurrence of the damage and demonstrate that they are reasonably adopting the appropriate measures are not penalized, although it is still a controversial position, as it could be understood as a form of covert amnesty (Deniz Mayor 2007). Regarding the comparison of accounting regulations between Portugal and Spain, there are no significant differences between the two regulations in force, although there is a certain delay in Portugal, compared to Spain, in terms of research in Environmental Accounting. In Monteiro and Guzmán's (2007) opinion, said discrepancy between the two countries may be due to the fact that Spain has had specific environmental accounting regulations since 1998, which have been improved with the approval of ICAC (2002). In Portugal, the late accounting regulation of environmental issues has probably contributed to delaying the incorporation of this line of research in the Portuguese scientific community. According to Cormier and Magnan (2003), it appears that French companies provide less extensive voluntary environmental reports than North American companies, and environmental reports in France are less institutionalized or subject to rituals than in Canada. Accounting legislation in Poland has been later than in Spain. As of 2017, publicly listed companies in Poland have been forced to publish nonfinancial information. This is due to the implementation of Directive 2014/95/EU in Polish law, which requires the disclosure of nonfinancial information to large public interest companies and specific capital groups (Szadziewska et al. 2018).

Corporate Social Responsibility uses four strategic lines that are (Cajiga Calderón 2013) business ethics, quality of life in the company, commitment to the community, and care for the environment (Pérez Espinoza et al. 2016). If the company does not have an adequate record of its environmental impacts and activities, we will not be complying with these strategies and there will be no responsible, complete, and transparent decision-making. The key aspects of corporate social responsibility related to the environment that we can distinguish in environmental accounting would be the reduction of costs derived from current and future compliance with the regulations (Dechant and Altman 1994; Hart 1995; Shrivastava 1995), obtaining efficiencies in the use of resources and emissions generated, which implies a reduction in operating costs (Russo and Fouts 1997; Shrivastava 1995), creation of competitive advantages through differentiation strategies (Shrivastava 1995), and the elimination of costs derived from negative stakeholder reactions and improved company image (Dechant and Altman 1994; Hart 1995; Shrivastava 1995).

Analyzing the results obtained and the legislation, it is possible to obtain a list of aspects that Spanish companies are legally obliged to publish:

- Environmental policies and certifications

- Fixed assets, assets of an environmental nature

- Provisions and contingencies

- Information on environmental issues

- Environmental Expenses

- Valuation methods and criteria, registration and valuation rules

- Environmental taxation

- Environmental incentives 
- Damage and measures

- $\quad$ Fines and penalties

- $\mathrm{CO}_{2}$ emissions and emission rights

The role of education in the incorporation of these values of social responsibility and ecological awareness increases day by day, so more and more attention should be paid to the training of students towards a society in which aspects are highlighted, key as humanitarian well-being, social equity, reducing environmental risks and protecting our planet (Wajeetongratana 2017). According to Ntanos et al. (2020), the students are environmentally sensitive but have limited knowledge of the scope of Social and Environment Accounting, although they express their interest to learn more about this new accounting area. Also, Suhardiyah (2019) conclude that college has a large role in assisting preservation of the environment, especially to instill the environmental awareness in students. Educational policy-makers can enrich the curricula of Business Administration and Accounting students with environmentally oriented courses and teaching methods that can increase the active participation of students (Kyriakopoulos et al. 2020).

\section{Conclusions and Future Research Orientations}

After the 2008 study mentioned above, more legislation has been published and some of the existing ones have been revised, but they are still too general. It must be concluded that it is necessary to issue the most demanding regulations with the obligation of companies to publish environmental information.

The Spanish regulation regarding environmental accounting constitutes a significant milestone in the matter, not only at the national level, but even in the European and world context, being a reasonably valid model in the process of environmental awareness of the relevant interest groups.

If we focus on comparing the laws of other states, another of the conclusions obtained is that the governments of the different countries must design environmental legislation considering the existence of environmental financial statements that could collect the assessment of the impact of the different activities carried out by the companies. In addition to the elaboration of new regulations and the inclusion of environmental aspects in existing regulations, it is urgent to interpret and clarify existing accounting standards and modify them where necessary.

The implementation of corporate social responsibility within companies demands greater transparency in information, which would improve internal company decision-making, as well as decision-making by external stakeholders such as customers, suppliers, investors, shareholders, or environmental organizations, among others. It is concluded, then, that corporate social responsibility is not a compliance with legal minimums but must be a commitment of the company to exceed these established minimums and thus improve its transparency.

The current accounting legislation related to environmental aspects regulates the aforementioned issues in the results. This information is used directly in the environmental management systems, sustainability reports, and other systems that measure the company's contribution to corporate social responsibility; in this way, all the environmental accounting information is directly related to the development of responsibility strategies, social by companies. The better the information system, the better the decision-making and corporate social responsibility policies implemented by organizations.

As a final conclusion, all those companies wishing to commit to corporate social responsibility must publish, in addition to the aspects required previously treated, other social and environmental information, as can be: systems environmental management; strategic plans; sustainability indexes (Dow Jones Sustainability, FTSE4Good Index ... ); management of environmental hazards; environmental research and innovation; information on sustainability; or environmental formation, among others. All these aspects are part of a good environmental responsibility policy for companies.

Education must become one of the main axes in the environmental awareness of students and society in general, including values of social and environmental responsibility in their activities 
and study plans, and influencing knowledge of environmental accounting, such as awareness and action tool.

This line of research has a long track record at a theoretical level, its practical side being a novel line due to the lack of specific literature on the actual implementation of Environmental Accounting. A future line of work could be the study of the effects of the implementation of environmental accounting in certain sectors and their evolution. In addition, this line of work has the ability to unite several complementary areas, economics, law, and the environment, making it a multidisciplinary investigation. According to Montero and Betancur (2018), the research possibilities in this area are endless, so an interesting work would be to identify the interrelationships between sustainable development and accounting in order to establish links, roles, and effects, as well as finding a way to link the environmental accounting with financial accounting making the information generated affordable.

Funding: This research received no external funding.

Conflicts of Interest: The author declares no conflict of interest.

\section{References}

Abadía, José Mariano Moneva, Carlos Larrinaga González, and Carmen Fernández Cuesta. 2002. Resolución del ICAC sobre reconocimiento, valoración e información de aspectos medioambientales en las cuentas anuales. AECA: Revista de la Asociación Española de Contabilidad y Administración de Empresas 61: 31-35.

Amay-Vicuña, Rocío Karina, Ivonne Narváez Zurita, and Juan Carlos Erazo Álvarez. 2020. La contabilidad ambiental y su contribución en la responsabilidad social empresarial. Dominio de las Ciencias 6: 68-98.

Ariel, Daniele, Silvia Fernández, and Laura Gorbach. 2001. Concepto sobre contabilidad y medioambiente: Referencias a un caso regional. In Anuario Facultad Ciencias Económicas. Rivadavia: Universidad Nacional de la Patagonia San Juan Bosco (U.N.P.S.J.B).

Bearden, David M. 2012. Comprehensive Environmental Response, Compensation, and Liability Act: A Summary of Superfund Cleanup Authorities and Related Provisions of the Act. Washington, DC: Library of Congress, Congressional Research Service.

Blanco Richart, Enrique. 2006. Influencia de la Legislación en la Información Medioambiental Suministrada por las Empresas. Un Estudio Regional. Ph.D. thesis, Universidad Rey Juan Carlos, Móstoles, Spain. Available online: http://www.eumed.net/tesis/2006/erbr (accessed on 10 December 2018).

Boulding, Kenneth Ewart. 1966. The Economics of the Coming Spaceship Earth. Radical Political Economy: Explorations in Alternative Economic Analysis. Washington, DC: Johns Hopkins University Press.

Brundtland, Gro Harlem. 1988. Report of the World Commission on Environment and Development: Our Common Future. Madrid: Ed. Alianza.

Cajiga Calderón, Juan Felipe. 2013. El Concepto de Responsabilidad Social Empresarial. Mexico City: CEMEFI.

Calero, Julio Cesar Maldonado, and Miriam Paulina Viteri Martinez. 2017. Contabilidad, responsabilidad social corporativa y sostenibilidad. Revista Publicando 3: 579-88.

Carrasco Fenech, Francisco, and Carlos Larrinaga Gonzalez. 1996. El poder constitutivo de la contabilidad: Consideraciones sobre la cuestión medioambiental. In Ensayos sobre Contabilidad y Economía. ICAC Tomo II. Madrid: Instituto de Contabilidad y Auditoría de Cuentas.

Carson, Rachel. 1962. Silent Spring. London: Penguin.

Centeno, María Esperanza Calvo. 2017. Información no Financiera Divulgada por las Empresas del IBEX 35: Análisis de la Contribución a los Objetivos de Desarrollo Sostenible de Naciones Unidas. Ph.D. dissertation, Universidad Europea de Madrid, Madrid, Spain.

Cerna, Oswaldo J. Vasquez. 2017. Contribución de la Ciencia Contable y Empresarial a la Gestión de la Responsabilidad Social de las Empresas y la protección del Medio Ambiente. LOGOS 7. [CrossRef]

Chein Schekaiban, nazlhe faride, and Maria Eugenia de la Rosa Leal. 2007. Tipología de la contabilidad medioambiental. Organizações em Contexto 3. [CrossRef]

Colby, Michael E. 1991. Environmental management in development: The evolution of paradigms. Ecological Economics 3: 193-213. [CrossRef] 
Cormier, Denis, and Michel Magnan. 2003. Environmental reporting management: A continental European perspective. Journal of Accounting and Public Policy 22: 43-62. [CrossRef]

Criado Jiménez, Irene, Chulián Manuel Fernández, and Francisco Javier Husillos Carqués. 2005. Cumplimiento con la divulgación de aspectos medioambientales en las cuentas anuales: El caso de España 2001-2003. Paper presented at XIII Congreso AECA-Armonización y gobierno de la diversidad, Oviedo, Spain, September 22-24.

Dahlsrud, Alexander. 2008. How corporate social responsibility is defined: An analysis of 37 definitions. Corporate Social Responsibility and Environmental Management 15: 1-13. [CrossRef]

de la Rosa Leal, María Eugenia. 2019. La Congruencia de la contabilidad ambiental en la normatividad contable nacional. Contabilidad y Auditoría. 49. Available online: https://ojs.econ.uba.ar/index.php/Contyaudit/article/ view/1337/2061 (accessed on 2 February 2020).

Dechant, Kathleen, and Barbara Altman. 1994. Environmental leadership: From compliance to competitive advantage. Academy of Management Perspectives 8: 7-20. [CrossRef]

Deniz Mayor, Juan José. 2007. La regulación de la información contable medioambiental en España. Contaduría y Administración 221: 163-92.

Déroche, Germain, and Birgit Penzenstadler. 2018. An analysis of best practice patterns for corporate social responsibility in top IT companies. Technologies 6: 76. [CrossRef]

European Commission. 2000. Directorate-General for Environment, Nuclear Safety, \& Civil Protection. White Paper on Environmental Liability; Office for Official Publications of the European Communities. Available online: https://ec.europa.eu/environment/legal/liability/pdf/el_full.pdf (accessed on 14 May 2020).

European Commission. 2001. Green Paper: Fostering a European Framework for Corporate Social Responsibility; Office for Official Publications of the European Communities. Available online: https://ec.europa.eu/ transparency/regdoc/rep/1/2001/EN/1-2001-366-EN-1-0.Pdf (accessed on 14 May 2020).

European Union. 2016. Paris Agreement. Available online: https://ec.europa.eu/clima/policies/international/ negotiations/paris_en (accessed on 14 May 2020).

Fundació Fòrum Ambiental. 1999. Contabilidad Ambiental: Medida, Evaluación y Comunicación de la Actuación Ambiental de la Empresa. Barcelona: Agencia Europea del Medio Ambiente.

Gomes, Ana de Lourdes Torralbas Blazquez, Emanuel Leite, and Guadalupe González García. 2020. Contabilidad ambiental: Desde una visión de responsabilidad social. Journal of Professional Business Review 5: 6-10.

González, Oliver Fernández. 2008. Contabilidad Medioambiental: Liderazgo e Información. Revista Española de Financiación y Contabilidad XXXVII: 601-2.

Hart, Stuart L. 1995. A natural-resource-based view of the firm. Academy of Management Review 20: 986-1014. [CrossRef]

Hediger, Werner. 2018. The Corporate Social Responsibility of Hydropower Companies in Alpine Regions-Theory and Policy Recommendations. Sustainability 10: 3594. [CrossRef]

IFAC. 1998. 1010 - Consideraciones Sobre el Medio Ambiente en la Auditoría de los Estados Financieros, en Normas Internacionales de Auditoría. Madrid: IFAC-IACJCE.

Kyriakopoulos, Grigorios, Stamatios Ntanos, and Sofia Asonitou. 2020. Investigating the environmental behavior of business and accounting university students. International Journal of Sustainability in Higher Education 21. [CrossRef]

Larrinaga, Carlos, Jose M. Moneva, and Eduardo Ortas. 2019. Twenty-Five Years of Social and Environmental Accounting in Spain: Past, Present and Future. Spanish Journal of Finance and Accounting. Available online: https://ssrn.com/abstract=3402912 (accessed on 18 September 2019).

Laudal, Thomas. 2012. Rising externality costs and corporate social responsibility case: EU legislation on electric and electronic equipment. Social Responsibility Journal 8: 289-304. [CrossRef]

Llodrà, Maria J. Masanet, Gilet Antoni Llull, and Val Mrr. 2008. La información medioambiental en el marco conceptual de la NIIF y la regularización española: Su aplicación en el caso de los pasivos. Revista de Contabilidad y Dirección 7: 135-62.

Meadows, Donella H., Dennis L. Meadows, Jorgen Randers, and William W. Behrens. 1972. The limits to growth. New York 102: 27. 
Mejia, Eutimio, and Luis Alberto Vargas Marín. 2012. Contabilidad para la sostenibilidad ambiental y social. Lúmina 13: 48-70. [CrossRef]

Mejia Soto, Eutimio. 2010. Contabilidad Ambiental, Crítica al Modelo de Contabilidad Financiera. Armenia: Universidad del Quindío.

Monteiro, Sonia Maria Da Silva, and Beatriz Aibar Guzmán. 2007. La regulación contable medioambiental: Análisis comparativo entre Portugal y España. Tékhne-Revista de Estudos Politécnicos 7: 253-90.

Montero, Monica, and Estefania Betancur. 2018. Una mirada a la contabilidad ambiental. Postulados y retos. Contaduría Universidad de Antioquia 73: 199-209. [CrossRef]

Mukherjee, Kajari. 2017. Mandated Corporate Social Responsibility (mCSR): Implications in Context of Legislation. In International Business Strategy. London: Palgrave Macmillan, pp. 421-39.

Ntanos, Stamatios, Sofia Asonitou, Grigorios Kyriakopoulos, Michalis Skordoulis, Miltiadis Chalikias, and Garyfallos Arabatzis. 2020. Environmental Sensitivity of Business School Students and Their Attitudes towards Social and Environmental Accounting. In Strategic Innovative Marketing and Tourism. Cham: Springer, pp. 195-203.

Pérez Espinoza, Maria José, Cacibel Espinoza Carrión, and Beatriz Peralta Mocha. 2016. La responsabilidad social empresarial y su enfoque ambiental: Una visión sostenible a futuro. Revista Universidad y Sociedad 8: 169-78.

Provencio, Enrique. 2002. La Cumbre de Johannesburgo o el desarrollo a la defensiva. Economía Informa. Septiembre. Available online: http://enpro.mx/publica/prov-johan.pdf (accessed on 1 December 2018).

Reverte Maya, Carmelo. 2015. La nueva Directiva Europea de Reporting no Financiero: Una excelente oportunidad para la mejora de la transparencia empresarial y del contenido del informe de gestión. Revista AECA 110: 17-22.

Rodriguez, Jaime. 2014. La contabilidad medioambiental ecológica o verde. Contable 50: 16-17.

Russo, Michael V., and Paul A. Fouts. 1997. A resource-based perspective on corporate environmental performance and profitability. Academy of Management Journal 40: 534-59.

Shrivastava, Paul. 1995. The role of corporations in achieving ecological sustainability. Academy of Management Review 20: 936-60. [CrossRef]

Soloeta, Iñaki Esparta. 2012. La falta de consenso en torno a la economía verde. Paper presented at CONAMA 2012, Congreso Nacional de Medio Ambiente, Madrid, Spain, November 26-30.

Suhardiyah, Martha. 2019. Implementation of environmental accounting in higher education solutions to improve the college's role in the implementation of corporate social responsibility. In IOP Conference Series: Earth and Environmental Science. Bristol: IOP Publishing, vol. 245, p. 012027.

Szadziewska, Arleta, Ewa Spigarska, and Ewa Majerowska. 2018. The disclosure of non-financial information by stock-exchange-listed companies in Poland, in the light of the changes introduced by the Directive 2014/95/EU. Zeszyty Teoretyczne Rachunkowości 99: 65-95. [CrossRef]

Tarruella, Anna Tena. 2005. Protocolo de Kioto. Situación de partida y efectos sobre los costes de las empresas españolas desde diferentes perspectivas de cambio tecnológico. Revista Iberoamericana de Contabilidad de Gestion 5: 193-207.

Tua Pereda, Jorge. 2002. Normas Internacionales de Contabilidad y Auditoría sobre la incidencia del medio ambiente en la información financiera. Revista de Contabilidade e Comercio 231: 547.

United Nations. 2012. The future we want. Paper presented at United Nations Conference on Sustainable Development Outcome Document, Janeiro, Brazil, June 20-22. UNCSD.

United Nations. 2015. Department of Economic and Social Affairs Disability of United Nations. Available online: https://www.un.org/development/desa/disabilities/envision2030.html (accessed on 17 March 2019).

United Nations. 2018. Climate Change, 2018. Available online: https://www.un.org/en/climatechange/cop24.shtml (accessed on 17 March 2019).

United Nations. 2019. Sustainable Development. Available online: https://sustainabledevelopment.un.org/?page= view\&nr=2982\&type=13\&menu=1634 (accessed on 17 October 2019).

Wajeetongratana, Prateep. 2017. Environmental Accounting for Modern Business: Social Responsibility or Economic Competitiveness? (The Case of Thailand). International Journal of Ecological Economics E Statistics 38: 123-32. 
Wirth, Maria Cristina. 2001. Acerca de la Ubicación de la Contabilidad en el Campo del Conocimiento. Buenos Aires: Editorial La Ley.

Zabala Luna, María Camila. 2016. Relación de la Contabilidad Ambiental y las Normas Internacionales de INFORMACIÓN financiera: Mini Revisión de Literatura. Bachelor's thesis, Facultad de Ciencias Económicas y Administrativas, Guasave, Mexico. 